J. Perinat. Med.

3 (1975) 115

\title{
External cephalic version under tocolysis
}

\author{
Erich Saling, Wolfgang Müller-Holve \\ Unit of Perinatal Medicine - The Free University of Berlin \\ Department of Obstetrics and Gynecology, Berlin-Neukölln
}

Received February 18, 1975. Accepted March 27, 1975.

Discussion of the management of breech deliveries in the past few years has focused basically upon two procedures:

1. An approach increasing favoring a cesarean section [5,11]. The maternal risk is about three times higher than with a vaginal delivery [4].

2. A somewhat more conservative approach whose goal is a vaginal breech delivery after continuous fetal monitoring. With this approach the risk to the fetus continues to be increased since asphyxic and traumatic complications during the second stage of labor and during delivery cannot be predicted despite intensive monitoring.

Since May 1974 we have utilized a third method of managing breech deliveries: External cephalic version from breech to vertex presentation. This method, of course, has been known in principle for a long time and was already described in the writings of Hippocraticians approximately in the fourth century B. C. [1]. We utilize, however, a new aid which considerably improves the condition of the version. In order to employ the version at an obstetrically favourable time, i. e. close to term, we give the patient a tocolytic drug and usually an inhalation analgesic before and during the version.

The method offers two substantial advantages over the conventional procedure of external version which usually has been considered as impossible during the last weeks of gestation $[7,8]$ :
1. In only a few cases will there be a reversion to the breech presentation close to term because of the relatively decreased space for fetal movements during the last month of pregnancy.

2. If a complication occurs during external version an immediate surgical delivery of the fetus close to term is possible.

The following prerequisites for the execution of an external version from a breech into a vertex presentation are considered necessary:

1. The external version should be carried out in a hospital with the capability for external cardio-tocography and immediate cesarean section.

2. There must be no uterine hemorrhage and placenta previa should be ruled out preferably by ultrasound.

3. The informed consent of the patient must have been obtained.

\section{Procedure}

After we have carried out these prerequisites for external version we proceed as follows: After an explanatory interview in the prenatal care unit, the patient is scheduled for the version after the 37 th week. This will be done as an outpatient procedure.

Ultrasonography yields the following information: lie, presentation, attitude, estimated fetal weight, from biparietal and thoracic diameter, localization of the placenta and the estimated amount of amniotic fluid. It is particularly im- 
portant to recognize a breech presentation with extended legs ("frank breech"), because in these cases we have found that the chances for a successful version is lower. After the initial ultrasonographic examination the cardiotocogram is recorded. If there are no abnormalities in the fetal heart rate, the version procedure is begun. The patient should be positioned with slightly bent legs on her left side (about $15^{\circ}$ ) on a mobile stretcher which is fixed for the procedure. Then she is asked to breathe a $0.37 \%$ penthrane-air mixture through a mask. Equally suitable is a nitrous oxide/oxygen mixture of $4: 2$ litres per minute. Simultaneously the patient is given 5 micrograms per minute intravenously Fenoterol*, a betamimetic tocolytic agent. Recently, we have added $10 \mu \mathrm{g}$ Verapamil** per $1 \mu \mathrm{g}$ Fenoterol in the same solution to prevent possible cardiovascular side effects of Fenoterol. After a dose of 20 to $50 \mu \mathrm{g}$ Partusisten ${ }^{\circledR}$ (we recently increased the dose) the version is carried out.

The operator places his hands low enough until a good area of approach to the forhead of the fetus has been found (Fig. 1). The head is then

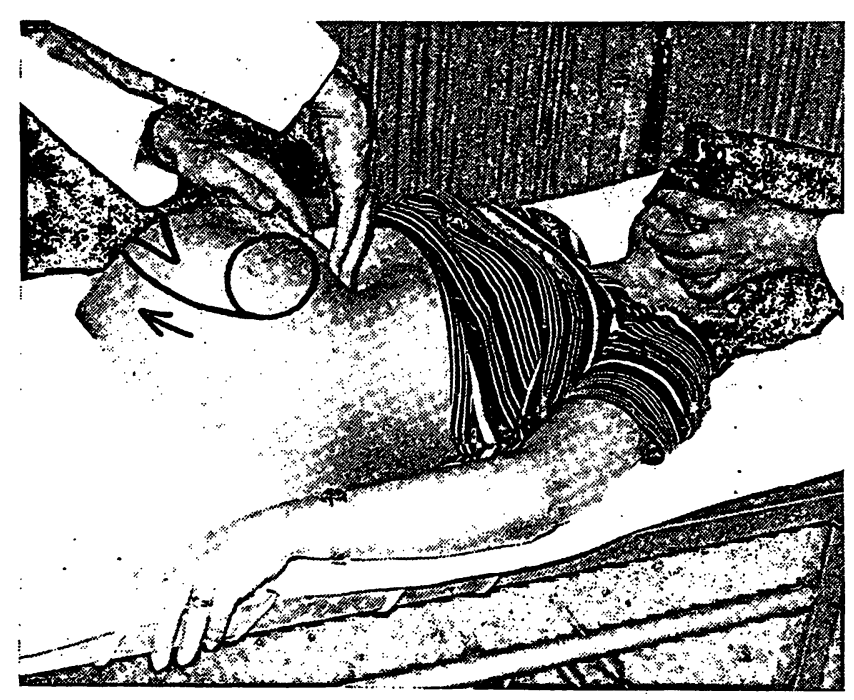

Fig. 1. Technique of the version.

pushed caudally by a slow alternating progression of the hands so that the fetus rolls over backwards. If the first attempt is unsuccessful the procedure can be repeated according to the patient's

\footnotetext{
* Partusisten @ (Boehringer Comp., Ingelheim, Germany) ** Isoptin ® (Knoll Comp., Ludwigshafen, Germany)
}

condition. It is recommended to have an assistant push the breech in the opposite direction out of the maternal pelvis. This can be effected either externally by the application of the assistant's hands above the symphysis or vaginally with two fingers in the posterior fornix. If the version has not been accomplished after these measures it is recommended to continue the use of the tocolytic drug in order to produce a more pronounced relaxation of the uterus. Without any incident attributable to the increased dosage of the Partusisten ${ }^{\circledR}$ we have reached a maximal dose of $100 \mu \mathrm{g}$ per session with the described slow injection speed. In 23 cases the dose was 50 micrograms or more per session.

In 18 cases where the version did not succeed immediately with the described technique, we have attempted to use the reverse method which is usually cited in the literature, namely that in which the pushing hand does not manipulate the head but the breech. With this technique we were able to complete the version successfully in six of the 18 cases. The first mentioned technique appears to be particularly suitable for a version close to term. The success of the version should be documented by an ultrasound examination and in order to assure the continued well-being of the fetus cardiotocography should be done immediately after the version.

\section{Results}

From May 10, 1974 until March 31, 1975 we attempted a version in 57 pregnant women in 67 sessions. One patient had to be scheduled three times and eight patients twice each for the attempted version. In 3 patients we attempted a version under anesthesia in one of these cases with success.

There were 43 successful versions of 57 patients with breech presentation (75\%). If patients are selected critically (i. e. exclusion of cases with ruptured membranes or cases after onset of labor) the success rates will be higher: about $80 \%$.

Of the 57 patients who have undergone a version, 54 have delivered: 14 as breeches and 40 as vertex presentations $(74 \%)$. In order to review how much the incidence of breech deliveries has 
changed in our service since the introduction of the external version near term with the aid of a tocolytic drug we compared the number of the breech deliveries, both mature and low birth weight infants before and after the introduction of the new method of external version (Tab. I).

Tab. I. Frequency of breech deliveries during the period before introduction of version (left) and since introduction of the version (right).

Comparison of normal weight and low birth weight singletons and twins.

\begin{tabular}{|l|l|l|l|l|}
\hline & \multicolumn{2}{|l|}{$\begin{array}{l}1.1 .1973 \text { to } \\
9.5 .1974 \\
\text { all births } \\
\mathrm{n}=2291\end{array}$} & \multicolumn{2}{|l|}{$\begin{array}{l}\text { 10.5.1974 to } \\
26.3 .1975 \\
\text { all births } \\
\mathrm{n}=1702\end{array}$} \\
\hline Breeches & $\mathrm{n}$ & $\%$ & $\mathrm{n}$ & $\%$ \\
\hline $\begin{array}{l}\text { Singletons } \\
\leq 2500 \mathrm{~g}\end{array}$ & 23 & 1.0 & 16 & 0.9 \\
\hline $\begin{array}{l}\text { Singletons } \\
>2500 \mathrm{~g}\end{array}$ & 88 & 3.8 & 28 & 1.6 \\
\hline Twins $\leq 2500 \mathrm{~g}$ & 5 & 0.2 & 4 & 0.2 \\
\hline Twins $>2500 \mathrm{~g}$ & 7 & 0.3 & 1 & 0.1 \\
\hline Total & 123 & 5.4 & 49 & 2.9 \\
\hline
\end{tabular}

The decrease in the number of actual breech deliveries in single low birth weight infants (2.500 grams birth weight and less) after the introduction of the version is not significant. On the other hand, there was a highly significant reduction in the number of breech deliveries with a birth weight of over 2500 grams by $2.2 \%$ from $3.8 \%$ to $1.6 \%(2 \mathrm{p}<0.001)$ after the procedure has been introduced. A comparison of twin breech infants was not feasible because of the small number of cases. The total number of breech infants declined during the study period significantly, namely by $2.6 \%$, from $5.4 \%$ to $2.9 \%(2 \mathrm{p}<0.01)$.

The decreased fetal risk is demonstrated convincingly by a comparison of the status of the newborns. The effect on the improvement of the clinical and acid-base status of the newborns is shown in Tab. II. All acidotic ( $\mathrm{pH}$ $<7.20$ ) and clinically depressed (Score $\leqq 6$ ) infants were evaluated both before and after the introduction of version. A separate evaluation was performed with the severely acidotic $(\mathrm{pH}$ $<7.1$ ) and the severely clinically depressed infants (Score $\leqq 4$ ).

The status of all infants born from breech presentation before the introduction of version is depicted (in column a). This is compared with the results from the period during which version was practiced (column b); which was subdivided into two groups: the first group contains all infants delivered as breeches (failures of version or cases diagnosed too late) and all potential breech infants, namely those who had been converted successfully and delivered from a vertex presentation. This combined group demonstrates how the situation had been improved for all infants (those converted and those not). The third group contains only those converted successfully and delivered as a vertex. This
Tab. II. Clinical status (C) and acidity status (A) before (column a) and after (column b) introduction of version in successfully converted infants born from vertex presentation (column c) and in all born infants in 1974 (column d).

\begin{tabular}{|c|c|c|c|c|c|}
\hline & & $a$ & 6 & c & d \\
\hline & & $\begin{array}{l}\text { Breech cases } \\
\text { before version } \\
n=338\end{array}$ & $\begin{array}{l}\text { Breech cases } \\
\text { and successfully } \\
\text { converted } \\
\text { infants } \\
n=89\end{array}$ & $\begin{array}{l}\text { Infants born in } \\
\text { vertex presentation } \\
\text { (successfully } \\
\text { converted) } \\
n=40\end{array}$ & $\begin{array}{l}\text { All born infants } \\
\text { in } 1974 \\
n=1867\end{array}$ \\
\hline \multirow{2}{*}{$\begin{array}{l}C \leq \| I I \\
(\leq 6 \text { Score })\end{array}$} & $n$ & 68 & 9 & 1 & 91 \\
\hline & $\%$ & 20,1 & $10.1>$ & 2.5 & 4.9 \\
\hline \multirow{2}{*}{$\begin{array}{l}A \leq I I I \\
(\mathrm{pH}<7.2)\end{array}$} & $n$ & 87 & 12 & 1 & 192 \\
\hline & $\%$ & 25.7 & 13.5 & 2.5 & 10.3 \\
\hline \multirow{2}{*}{$C$ and $A \leq I I I$} & $n$ & 37 & 2 & 0 & 42 \\
\hline & $\%$ & 10.9 & 2.2 & 0 & 2.3 \\
\hline \multirow{2}{*}{$\begin{array}{l}C \leq 11 \\
(\leqslant 4 \text { Score })\end{array}$} & $n$ & 16 & 2 & 0 & 29 \\
\hline & $\%$ & 4.7 & 2.2 & 0 & 1.6 \\
\hline \multirow{2}{*}{$\begin{array}{l}A \leq \pi \\
(p H<7.1)\end{array}$} & $n$ & 42 & 4 & 0 & 34 \\
\hline & $\%$ & 12.4 & 4.5 & 0 & 1.8 \\
\hline \multirow{2}{*}{$C$ and $A \leq I I$} & $n$ & 10 & 0 & 0 & 5 \\
\hline & $\%$ & 3.0 & 0 & 0 & 0.3 \\
\hline
\end{tabular}


demonstrates how much the risk for the successfully converted infants had been reduced. The remarkably good results (column c) cannot be considered conclusive because of the small number of cases. Our experience to date, however, indicates that converted infants born from a vertex presentation are exposed to no greater stress and thus to no greater risk than fetuses which had been in vertex presentation originally and were thus delivered. For general comparison purposes column $d$ of the table lists the status of our entire patient material.

The decreased percentage of all clinically depressed and acidotic infants between the first two groups in Tab. II is statistically significant $(2 \mathrm{p}<0.05)$. As expected, the difference between all infants born as breeches before the period of version and those born as ivertex presentation after a successful version is also significant $(2 p<0.025)$. The decrease in percentage of clinically severely depressed or acidotic infants could not yet be evaluated because of the small number of cases.

In Fig. 2 the number of patients subjected to an attempted version is listed by weeks of gestation and compared with the number of failures. The failure rate does not appear to increase with increasing gestational age. In contrast, RANNEY [8], Friedlander [2] and Sauter [10] reported an increased failure rate with increase in gestational age. MACARTHur [6] was unable to execute an external version after the 38th week of gestation. We were successful in 10 of 13 attempted versions after the 38th week of gestation. Parity and failure rate appeared not to be correlated in our procedure (Tab. III). This statement is of interest because the literature seems to report poor results with attempted versions in primigravidae $[2,3,8,10]$.

Tab. IV correlates maternal age and failure rate. In our first report on the use of tocolysis in external version of breeches close to term [9] we did not consider external version if the amount of amniotic fluid was reduced as determined by ultrasound. Meanwhile we have subjected nine patients with ultrasonographically demonstrated oligohydramnios to an attempted version. Four attempts were successful. In two cases we attemp-

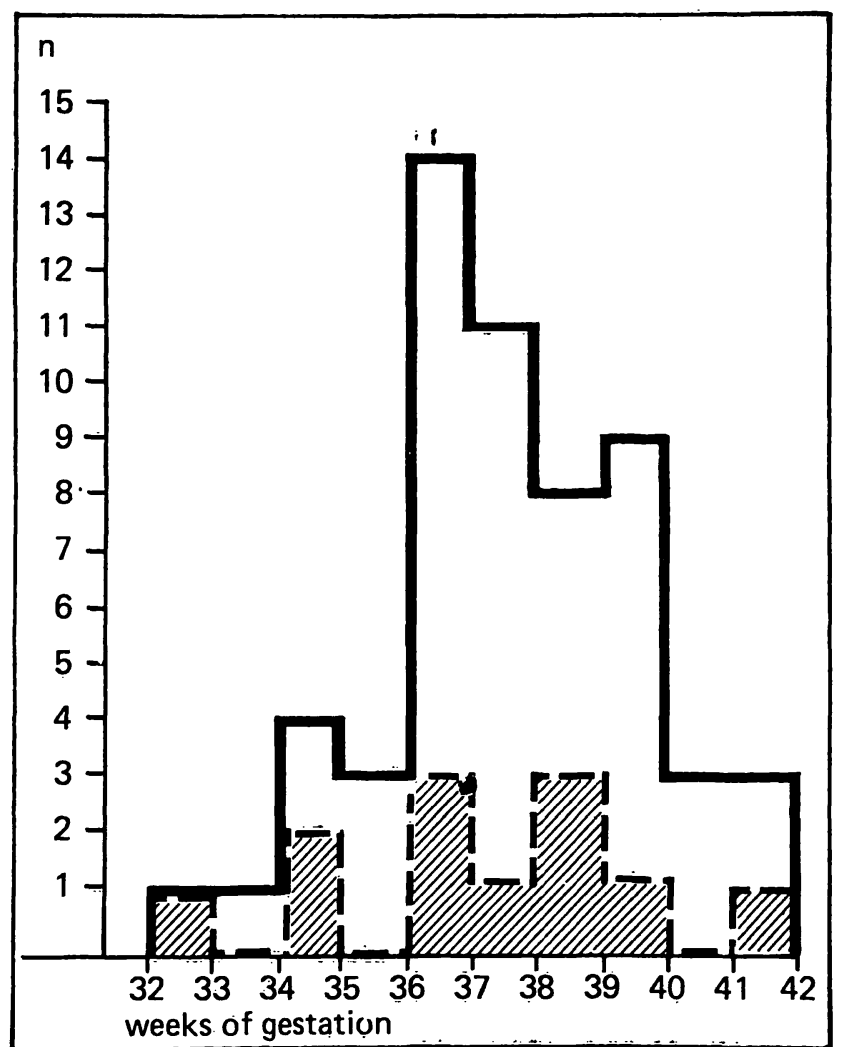

Fig. 2. Break-down of version cases according to weeks of . gestational age (solid line) and correlation with failures (interrupted line).

Tab. III. Version success and parity.

\begin{tabular}{|l|l|l|l|}
\hline Parity & I.-Para & II.-Para & ZIII.-Para \\
\hline $\begin{array}{l}\text { No. of } \\
\text { attempted } \\
\text { versions }\end{array}$ & 35 & 16 & 6 \\
\hline Failures & 10 & 4 & 0 \\
\hline
\end{tabular}

Tab. IV. Version success and maternal age.

\begin{tabular}{|c|c|c|c|c|}
\hline Maternal age & $<20$ & $20-29$ & $30-39$ & $>40$ \\
\hline $\begin{array}{l}\text { No. of } \\
\text { attempted } \\
\text { versions }\end{array}$ & 2 & 31 & 23 & 1 \\
\hline Failures & 1 & 6 & 7 & 0 \\
\hline
\end{tabular}

ted to carry out the version after the membranes had ruptured prematurely. However, no successes were seen with this condition.

In 6 term pregnancies where the patients were referred to us only at that time we attempted an external version during labor; this was successful in three cases. 


\section{Complications}

A transient acute bradycardia of 60 beats per minute was seen in one version under anesthesia which had become necessary because of markedly increased abdominal wall tension. Following the cessation of the severe bradycardia, late decelerations occurred 30 minutes after the attempted version. Because the attempted version failed and we had diagnosed fetal malnutrition by HPL and ultrasound examination the infant was delivered 30 minutes after the attempted version by cesarean section. The infant girl (1.630 grams, $40 \mathrm{~cm}, 33 \mathrm{rd}$ week of gestation, had a clinical score of 7 points, the umbilical artery $\mathrm{pH}$ was 7.02 and $\mathrm{pHqu} 40$ value was 7.19.

In another case of an attempted version under anesthesia spontaneous contractions occured and were associated with variable decelerations. Subsequent amnioscopy demonstrated thick green amniotic fluid. Fetal blood analysis showed normal $\mathrm{pH}$ values of actual 7.33 and $\mathrm{pHqu} 40$ 7.34. Because of a firm cervix and lack of progress in labor a cesarean section was performed 15 hours after the version. After delivery it was seen that the infant was small for dates without recognizable prenatal symptoms. The birth weight was 2260 grams and the length $48 \mathrm{~cm}$. The clinical score was 5 , umbilical artery $\mathrm{pH}$ values were actual 7.20 and qu 40 7.24.

We saw a mild cervical hemorrhage in one unsuccessfully attempted version. The hemorrhage stopped spontaneously and fetal monitoring over several hours showed no fetal distress.

There was no perinatal death due to an attempted version.

\section{Monitoring}

The evaluation of the fetal heart rate pattern was somewhat difficult. Because of the pronounced fetal movement after version and attempted version special equipment with a broad-angle ultrasound transducer appears to be necessary in order to get a useful cardiotocogram. Since only one of our monitors has such a transducer and this monitor is also utilized elsewhere we were not able to use it in all attempted versions. Instead, we used fetal pulse detectors for the auscultatory monitoring of fetal heart beats. Of 24 usable cardiotocograms five cases demonstrated a bradycardia immediately after the procedure with recovery when the mother was placed in the lateral recumbent position (Fig. 3). Except

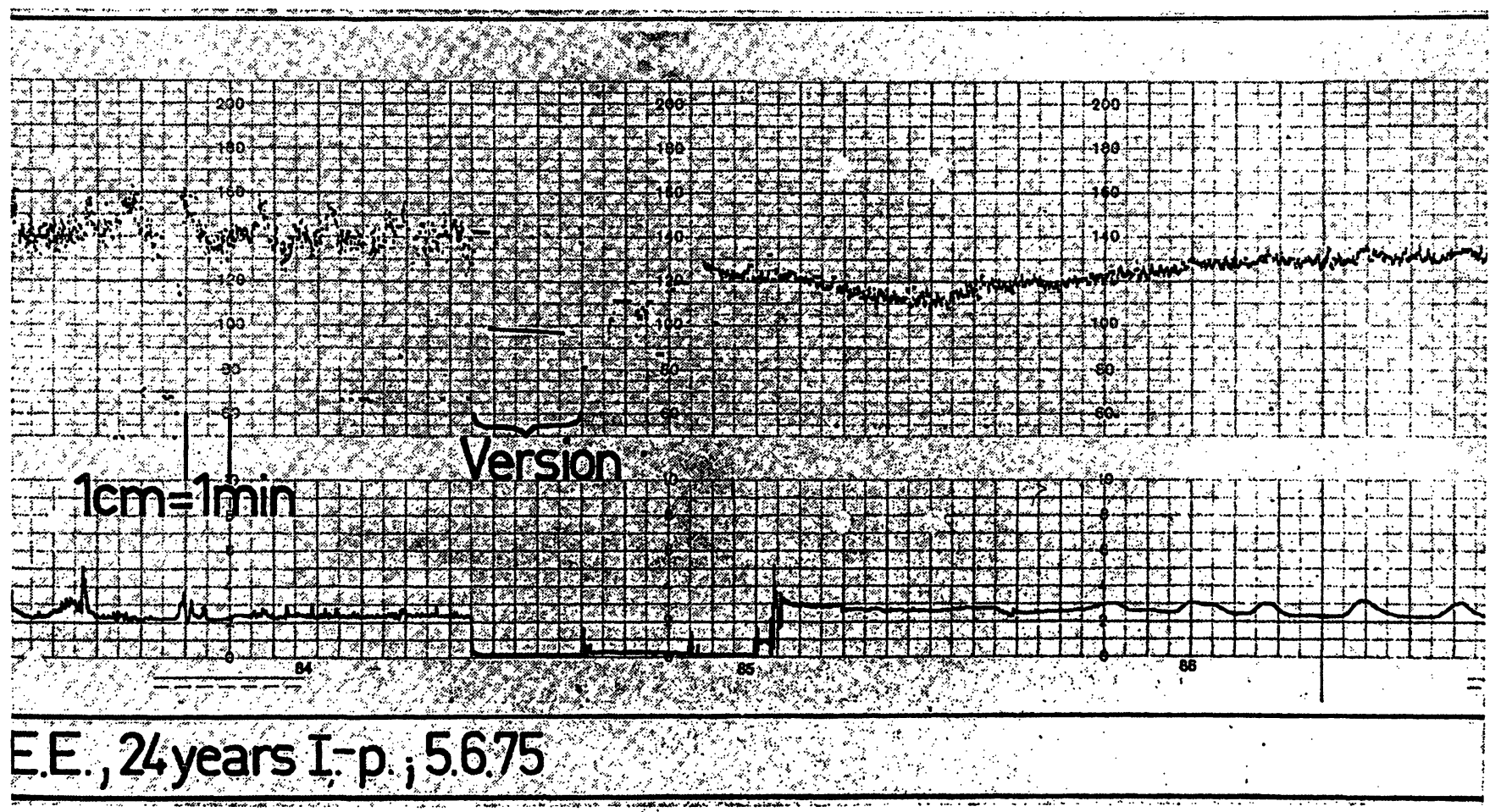

Fig. 3. Cardiotocogram with transient bradycardia immediately after version. 
for the two previously described cases, with late decelerations after the attempted version, this disturbance was seen in no other cases.

Two cases demonstrated a period with saltatory oscillations and a tachycardia with 180 beats per minute which disappeared after a few minutes.

If 15 minutes after a completed version there were no pathological heart rate patterns, we considered the fetal status as non-stressed. Except for a mild fetal tachycardia caused by betamimetics we did not see a suspicious cardiotocogram after this period in any case.

In reference to the occurrence of a breech with extended legs our initial observations prompt the following speculation. We have only recently begun to identify the fetal posture i. e. the correlation of the fetal parts to each other with our ultrasound screening procedures (Fig. 4); $\checkmark$ thus our numbers are still small and a definitive comment would be premature. However, the fact that among infants whose versions were unsuccessful and who were delivered as breeches all but one were delivered with extended legs suggests that the fetal trunk, because of splinting from the extended legs, cannot bend as easily and thus has a decreased chance for a successful version.

\section{Summary}

We currently consider the external version of the fetus from a breech to a vertex presentation near term the best solution to the disadvantages of a breech delivery for mother and child. Version at such a late time in gestation is only possible with the aid of the tocolytic relaxation of the uterus as recommended by us. This method offers two important advantages over the conventional method of external version, the performance of which after the 34th week of gestation has been discouraged because of the poor chance for success:

1. Because of the relatively decreased intrauterine space during the last month of pregnancy the fetus will revert less readily to a breech.

2. In the event of a complication during external version the immediate operative delivery of the mature infant near term is possible.

After the presentation of the fetus has been diagnosed by ultrasound the mother is given 20-50 micrograms Fenoterol (Partusisten $($ ) intravenously simultaneously with an

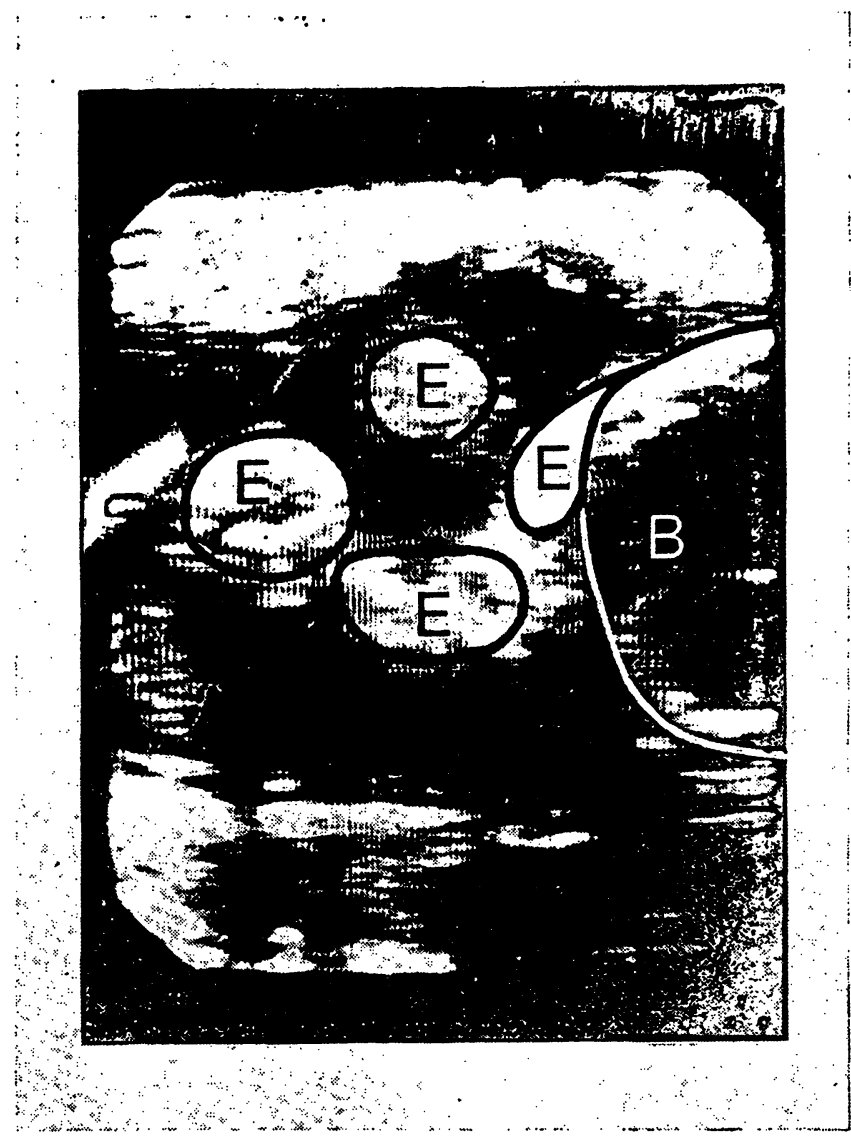

Fig. 4. Ultrasound image of the fetal pelvic area. The clearly visible double extremities in the lower portion of the fetal body rule against extended legs $(\mathrm{B}=$ breech, $\mathrm{E}=$ Extremities).

inhalation analgesia. The version itself is effected by positioning the hands of the operator against the fetal forehead and by turning the infant as in a backwards roll (Fig. 1). If this fails, the dose of the tocolytic agent may be increased. In cases with extended legs the chances for success appear to be decreased (Fig. 4). The completed version should be confirmed with an ultrasound examination and the undisturbed status of the fetus should be documented with a cardiotocogram immediately after the version.

The following results were achieved: The external version was successful in $\mathbf{4 3}$ of 57 pregnant women (75\%). If the material is selected more critically, over $80 \%$ of the attempted versions should be successful. We have now delivered 40 infants as vertex presentations after a previously diagnosed breech presentation. The frequency of breech deliveries in our hospital has decreased by $2.6 \%$ from $5.4 \%$ to $2.9 \%$ since the introduction of version (Tab. I). The decrease is statistically significant. Convincing evidence that version has decreased fetal risk from breech delivery is found in a comparison of the newborn status (Tab. II). 
The decrease in the percentages of clinically depressed and acidotic newborns is also statistically significant. The failure rate does not appear to increase with increasing gestational age (Fig. 2). There is no correlation between parity and failure (Tab. III) or between maternal age and failure
(Tab. IV). So far we have seen no serious complications. In 5 of 24 cardiotocograms tecorded a transient fetal bradycardia occured immediately after the version which disappeared after a few minutes of maternal lateral position (Fig. 3).

Keywords: Breech presentation, external version, late pregnancy, tocolysis.

\section{Zusammenfassung}

\section{Äußere Wendung unter Tokolyse}

Die äußere Wendung des Feten aus Beckenendlage in Schädellage in Terminnähe dürfte die derzeit beste Lösung darstellen, die Nachteile einer Beckenendlagengeburt für Mutter und Kind zu umgehen. Die Wendung zu einem so späten Zeitpunkt in der Schwangerschaft ist erst unter Zuhilfenahme der von uns empfohlenen tokolytischen Relaxation des Uterus möglich geworden. Diese Methode bietet zwei wesentliche Vorteile gegenüber dem konventionellen Vorgehen der äußeren Wendung, deren Durchführung früher nach der 34. Schwangerschaftswoche kaum Aussicht auf Erfolg bot:

1. In nur wenigen Fällen kommt es wegen des relativ eingeschränkten Bewegungsspielraumes des Feten im letzten Schwangerschaftsmonat noch zu einer Rückdrehung in Beckenendlage.

2. Sollte bei der äußeren Wendung eine fetale Komplikation auftreten, wäre eine sofortige operative Entbindung des in Terminnähe reifen Kindes möglich.

Nach vorheriger ultrasonographischer Klärung der Lage des Feten werden an die Schwangere $20-50 \mu \mathrm{g}$ Fenoterol (Partusisten $($ ) ) intravenös verabfolgt und gleichzeitig ein Inhalationsanalgetikum angeboten. Die Wendung selbst erfolgt durch Ansetzen der Hände des Operateurs an der Stirnseite des kindlichen Kopfes und durch Drehung des Kindes im Sinne einer Rückwärtsrolle (Fig. 1). Beim Mißlingen kann die Dosis des Tokolytikums erhöht werden. Liegen extended legs vor (Fig. 4), scheinen die Wendungschancen herabgesetzt zu sein. Zur Bestätigung der voll- zogenen Wendung sollten eine Ultraschall-Untersuchung und zur Sicherung der ungestörten Versorgung des Feten eine Kardiotokographie unmittelbar nach dem Wendungseingriff angeschlossen werden.

Folgende Ergebnisse konnten erzielt werden: Die äußere Wendung gelang bei 57 Schwangeren in 43 Fällen, das sind rund 75\%. Bei kritischer Auswahl des Materials sind in über $80 \%$ Erfolge zu erwarten. 40 Patientinnen mit einer vorher bestandenen Beckenendlage sind inzwischen nach der Wendung aus Schädellage entbunden worden. Die Häufigkeit von Beckenendlagengeburten an unserer Klinik vor und nach Einführung der Wendung ist von 5.4\% um 2.6 auf $2.9 \%$ gesenkt worden (Tab. I). Die Abnahme ist statistisch signifikant. Ein überzeugender Beweis für die durch die Wendung erzielte Abnahme der Gefahr für die Kinder geht aus der Gegenüberstellung des Neugeborenenzustandes hervor (Tab. II). Die Abnahme der Prozentsätze der klinisch deprimierten und der azidotischen Neugeborenen ist ebenfalls statistisch signifikant. Die Höhe der Mißerfolgsquote scheint mit steigender Schwangetschaftsdauer nicht zuzunehmen (Fig. 2). Es bietet sich auch kein Anhalt dafür, daß zwischen Paritäts- und Mißerfolgsquote (Tab. III) sowie zwischen Alter und Mißerfolgsquote (Tab. IV) Beziehungen bestehen.

Ernste Komplikationen haben sich in unserem Patientengut bisher nicht ereignet. Bei 5 von 24 durch Kardiotokographie überwachten Patientinnen lagen unmittelbar nach der Wendung fetale Bradykardien vor, die in Seitenlage der Patientinnen nach wenigen Minuten abklangen (Fig.3).

Schlüsselwörter: Beckenendlage, Spätschwangerschaft, Tokolyse, Wendung.

\section{Résumé}

Rotation extérieure du foetus sous tocolyse

La rotation extérieure du foetus de la position du siège en position du sommet à proximité du terme devrait être actuellement le meilleur moyen d'empécher les inconvénients d'un accouchement avec position du siège pour la mêre et l'enfant. La rotation à un stade si avancé de la grossesse n'est devenue possible qu'en recourant à la relaxation tocolytique de l'utérus que nous avions recommandée. Cette méthode offre les deux principaux avantages suivants sur le procédé conventionnel de la rotation extérieure dont l'application jusque là avait peu de chance de réussir après la 34 ème semaine de grossesse:

1. Le retour à la position du siège ne se produit que dans de rares cas étant donné l'espace relativement réduit des mouvements foetaux dans le dernier mois de grossesse. 2. Un accouchement opératoire immédiat de l'enfant mature est possible en cas de complication foetale consécutive à la rotatiog extérieure.

Après examen ultrasonographique préalable de la position du foetus, on injecte par voie intraveineuse aux femmes

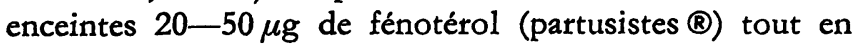
leur appliquant une inhalation d'analgétique. Pour la rotation même, l'opérateur pose ses mains sur le côté frontal de la tête foetale et fait tourner le foetus dans le sens d'un rouleau en arrière (fig. 1). En cas d'échec on peut augmenter la dose du tocolytique; si le foetus présente des extended legs (fig. 4), la rotation aura moins de chance de réussir. L'intervention devrait être immédiatement suivie 
d'un examen ultrasonique pour confirmation de la rotation complète et d'une cardiotocographie pour s'assurer de la condition normale du foetus.

Notre application de cette méthode a donné les résultats suivants: La rotation extérieure a réussi chez 43 des 57 femmes enceintes soumises à cette interventionm soit dans $75 \%$ des cas. Le succès devrait dépasser $80 \%$ en sélectionnant le matériel plus rigoureusement. Entre-temps, 40 patientes ayant subi avec succès une rotation de la position du siège ont accouché avec position du sommet. $\mathrm{La}$ fréquence des accouchements avec position du siège dans notre clinique a baissé de $2,6 \%$ pour passer de $5,4 \%$ à $2,9 \%$ depuis que nous avons introduit cette méthode (Tab. I). Cette baisse est statistiquement significative. On a une preuve convaincante de la diminution des dangers pour le foetus grâce à la rotation en comparant l'état des nouveaux-nés (Tab. II). De même, la proportion moindre des nouveaux-nés en mauvais état clinique et acidotiques est statistiquement significatike. Le pourcentage des échecs ne semble pas augmenter avec la durée de la grossesse (fig. 2). Il ne semble pas davantage qu'il existe des rapports entre le taux de parité et d'échec ('Tab. III) ainsi qu'entre l'àge et le taux d'échec (Tab. IV).

On n'a pas observé de complications sérieuses chez nos patientes. Chez 5 des 24 patientes surveillées par cardiotocographie aussitôt après la rotation, il s'est produit, certes, des bradycardies foetales aigues mais qui ont disparu au bout de quelques minutes après avoir fait allonger les patientes sur le côté (Fig. 3).

Mots-clés: Position du siège, rotation, stade avancé de la grossesse, tocolyse.

\section{Bibliography}

[1] Fasbender, H.: Geschichte der Geburtshilfe. Olms, Hildesheim 1964

[2] Friedlander, D.: External cephalic version in the management of breech presentation. Amer. J. Obstet. Gynec. 95 (1966) 906

[3] Hrbbard, L. T., W. R. Schumann: Prophylactic external cephalic version in an obstetric practice. Amer. J. Obstet. Gynec. 516 (1973) 511

[4] Hürer, J.: Die aktuelle mütterliche Sectio-Morbidität und -Mortalität in der BRD. Gynäkologe 8 (1975) 19

[5] KuBli, F.: Geburtsleitung der Beckenendlagen. Gynäkologe 8 (1975) 48

[6] MACARThUR, J.L.: Reduction of the hazards of breech presentation by external cephalic version. Amer. J. Obstet. Gynec. 88 (1964) 302

[7] Pschyrembel, W.: Praktische Geburtshilfe. De Gruyter, Berlin 1973
[8] RANNEY, B.: The gentle art of external cephalic version. Amer. J. Obstet. Gynec. 116 (1973) 239

[9] Saling, E., W. Müller-Holve: Die äußere Wendung des Feten aus Beckenendlage in Schädellage unter Tokolyse. Sitzung der Gesellschaft für Geburtshilfe und Gynäkologie in Berlin am 20. 9. 1974. Geburtsh. u. Frauenheilk. 35 (1975) 149

[10] SAUTER, H.: Die prophylaktische Wendung der Bekkenendlage während der Gravidität. Schweiz. med. Wschr. 12 (1961) 369

[11] Wedding, H.: Die Prognose des Beckenendlagenkindes. Aktive oder konservative Geburtsleitung? Bericht über Nachuntersuchungen an 1042 reif geborenen Beckenendlagenkindern aus der Zeit von 1959 bis 1973. 7. Deutscher Kongreß für Perinatale Medizin-Berlin 1974. In: Dudenhausen, J. W., E. Saling, E. Schmidt: Perinatale Medizin Band VI. Thieme, Stuttgart 1975

Prof. Dr. E. Saling

Dr. W. Müller-Holve

Unit of Perinatal Medicine

Mariendorfer Weg 28-38

D-1000 Berlin 44/Germany 